\title{
Behavior in Mus musculus of Schistosoma mansoni from mollusks treated with hydrocortisone
}

\author{
Comportamento em Mus musculus do Schistosoma mansoni \\ oriundo de moluscos tratados com hidrocortisona
}

\author{
Deborah Regina Serrano1, Eliana Maria Zanotti-Magalhães', \\ Luiz Augusto Magalhães ${ }^{1}$ and José Ferreira de Carvalho ${ }^{2}$
}

\begin{abstract}
Twenty mice were exposed to cercariae from mollusks treated with hydrocortisone and another 20 mice received cercariae from non-treated mollusks. The behavior of the parasites from the two groups of mollusks was compared based on the ability of cercariae to penetrate mice, on the total number of worms recovered after eight weeks of infection, on the relationship between the number of penetrating cercariae and the number of recovered worms and on the number of eggs in the feces. Treating the mollusks with hydrocortisone did not alter the ability of cercariae to penetrate mice nor did it affect the total number of worms recovered. The number of female worms, the number of coupled worms and the number of eggs in the feces were greater in mice infected by cercariae from mollusks treated with hydrocortisone.
\end{abstract}

Key-words: Schistosoma mansoni. Mus musculus. Hydrocortisone. Cercariae. Eggs.

\section{RESUMO}

Vinte camundongos foram expostos a cercárias oriundas de moluscos tratados com hidrocortisona e outros vinte receberam cercárias de moluscos não tratados. 0 comportamento dos parasitas dos dois grupos foi comparado com base na habilidade das cercárias em penetrar nos camundongos, no número total de vermes recuperados, após oito semanas de infecção, na relação entre 0 número de cercárias penetrantes e 0 número de vermes recuperados e 0 número de ovos nas fezes. 0 tratamento dos moluscos com hidrocortisona não alterou a habilidade das cercárias em penetrar nos camundongos nem afetou o número total de vermes recuperados. 0 número de vermes fêmeas, o número de vermes acasalados e 0 número de ovos nas fezes aumentaram em camundongos infectados por cercárias de moluscos tratados com hidrocortisona.

Palavras-chaves: Schistosoma mansoni. Mus musculus. Hidrocortisona. Cercária. Ovos.

The susceptibility of mollusks to infection by Schistosoma mansoni has a strong genetic component that determines the mollusks' metabolic and physiologic ability to interact with the parasite $^{1214}$. For each gene contributing to mollusk susceptibility there is a corresponding gene that determines parasite pathogenicity ${ }^{16}$. Cellular and humoral mechanisms are involved in the susceptibility of snails to trematode sporocysts ${ }^{14}$. In snails resistant to $\mathrm{S}$. mansoni an intense hemocytic reaction occurs around the sporocysts and eventually leads to their death, whereas in susceptible snails, the reaction is mild and most of the sporocysts remain viable ${ }^{23512}$.

We have previously demonstrated that hydrocortisone increases the susceptibility of Biomphalaria glabrata to Schistosoma mansoni ${ }^{17}{ }^{18}$. This increased susceptibility is associated with a reduction in number of hemocytes in the hemolymph and, consequently, little or no hemocytic reaction to S. mansoni. Susceptible snails carry a higher number of viable sporocysts which mature more rapidly, therebyincreasing the infection rate through

1. Departamento de Parasitologia do Instituto de Biologia da Universidade Estadual de Campinas, SP, Brasil. 2. Statistika Consultoria, Campinas, SP, Brasil. Financial support: FAPESP.

Address to: Dr. Luiz Augusto Magalhães. Deptō de Parasitologia/IB/UNICAMP. Caixa Postal 6109, Cidade Universitária, Barão Geraldo, 13083-970 Campinas, SP, Brasil.

Telefax: 5519 3289-3124.

e-mail: lam@unicamp.br

Recebido para publicação em 31/8/2004

Aceito em 18/6/2005 
a greater increase of cercariae. Greater susceptibility of the snails means that more cercariae can penetrate the definitive host to produce a higher number of adult worms ${ }^{21}$. Consequently, we have examined the behavior in mice (Mus musculus) of S. mansoni obtained from B. glabrata treated with hydrocortisone compared to those from mollusks not treated with hydrocortisone.

\section{MATERIAL AND METHODS}

Biomphalaria glabrata derived from specimens collected in Belo Horizonte (MG, Brazil) and housed in the Departamento de Parasitologia, Universidade de Campinas ( UNICAMP), were used. Two experimental groups consisting of 52 mollusks each were studied: group A comprised infected mollusks not treated with hydrocortisone and group B infected mollusks treated with hydrocortisone ${ }^{17}$. The snails of both groups were infected on the second day of hydrocortisone treatment and in group Abyexposing each snail to 10 miracidia of S. mansoni strain BH. Four weeks after exposure to miracidia, the snails were exposed to light and heat in order to obtain the cercariae needed to infect the mice. Mice were infected with S. mansoni cercariae from B. glabrata treated (Group I) or untreated (Group II) with hydrocortisone. Each group consisted of 20 female Swiss mice ( 18g, 30 days old) obtained from the Central Animal House at UNCAMP. The mice were infected by exposing the tail of each mouse to 60 cercariae for $2 \mathrm{~h}$. After exposure of the mice to S. mansoni cercariae, the number of penetrating cercariae was determined as the difference between the number of cercariae in each mouse and the number of non-penetrating cercariae ${ }^{8}$.

The number of eggs in the feces of infected mice was determined weekly starting from the fourth week of infection using Kato-Katz method ${ }^{6}$.

After eight weeks of infection, the surviving mice were sacrificed and the worms present in the mesenterium were collected by perfusion of the portal-mesenteric system ${ }^{19}$ and crushing the liver between glass plates. The worms were classified according to sex and the number of coupled worms was recorded.

Statistical analysis was realized through linear generalized models.

\section{RESULTS}

Treatment of the mollusks with hydrocortisone did not alter the ability of cercariae to penetrate the host ( $p=0.0737$ ) (Table 1).

There was no significant difference $(p=0.1332)$ in the number of penetrating cercariae between groups, or in the number of adult worms recovered from mice of both groups after eightweeks ofinfection (Table 1). However, the number of mated worms $(p<0.0001)$ and the total number of females were greater in mice infected by cercariae from snails treated with hydrocortisone, whereas the number of male worms was lower in this group $(\mathrm{p}<0.001)$ (Table 1).
Table 1 - Number of penetrating cercariae and recovered worms in Swiss mice exposed to 60 cercariae of Schistosoma mansoni from Biomphalaria glabrata treated (Group I) or untreated with hydrocortisone (Group II).

\begin{tabular}{lcc}
\hline & Group I* & Group II* \\
\hline Penetrating cercariae & $54 \pm 6$ & $55 \pm 3$ \\
Worms & & \\
$\quad$ female & $12 \pm 6$ & $4 \pm 1$ \\
$\quad$ male & $12 \pm 10$ & $27 \pm 12$ \\
mated & $8 \pm 4$ & $6 \pm 4$ \\
total & $41 \pm 14$ & $43 \pm 12$ \\
$\quad$ recovered (\%) & $75 \pm 24$ & $77 \pm 21$ \\
\hline Mean + SD & &
\end{tabular}

Mice infected with cercariae from mollusks treated with hydrocortisone ( Group I) were the first to release S. mansoni eggs in their feces (fourth week of infection). These rodents shed a greater number of eggs/gram of feces each week $(p<0.001)$ (Figure 1). At the end of the experiment, no difference was observed between the two experimental groups in relation to the ratio of number of eggs per gram of feces and the number of couples ( $p=0.1736$ and the survival of the mice $(p=0.0909)$.

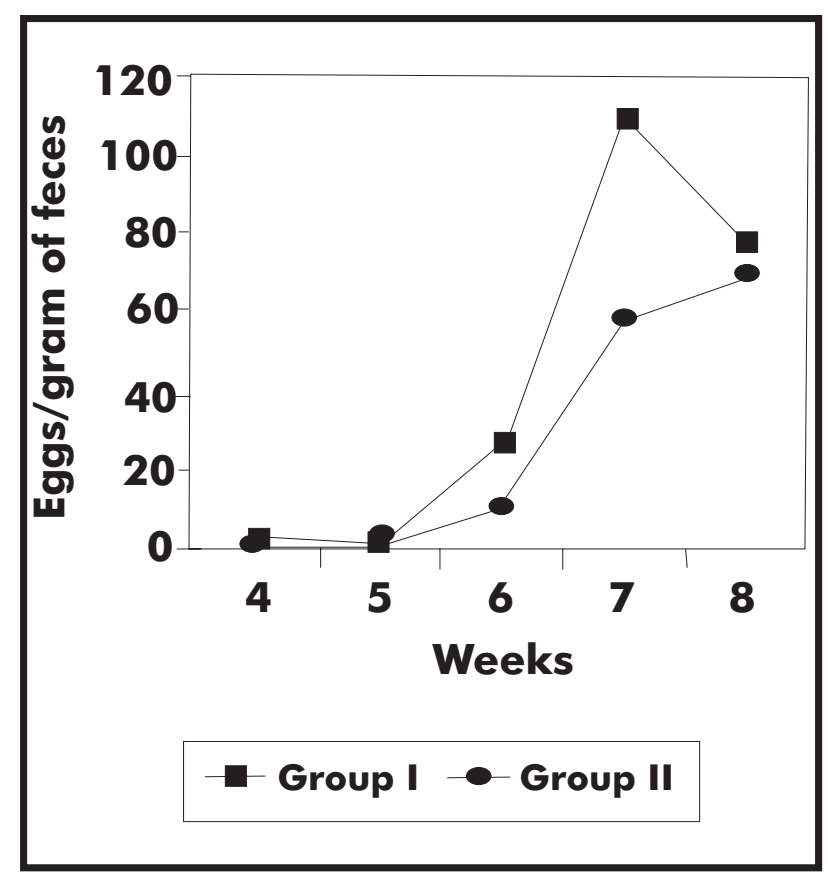

Figure 1 - Average weekly number of Schistosoma mansoni eggs expelled in the feces of mice infected with cercariae from Biomphalaria glabrata treated (Group I) or untreated (Group II) with hydrocortisone.

\section{DISCUSSION}

Cercariae of the BH strain penetrate mouse skin with more facility than those of the SJ strain, perhaps due to susceptibility of the intermediate host ${ }^{10}$. Although the hemocytic reaction around sporocysts is modest or absent in mollusks treated with hydrocortisone, and therefore similar to mollusks genetically selected for their susceptibility, the ability of cercariae produced in these mollusks to penetrate the tegument of mice was not 
greater than that of cercariae from non-treated mollusks. Agreater ability to penetrate for cercariae from B. glabrata genetically selected for their susceptibility has been reported ${ }^{21}$. In schistosomiasis, the adult parasitic load is less important since the pathogenesis is more related to the presence of granulomatous reactions around the parasite eggs. Thus, $\mathrm{BH}$ strain is more pathogenic than SJ strain because of the greater number of hepatic granulomas caused, though the number of worms produced by both strains is the same ${ }^{91011}$. In a study of the development of various geographical strains of S. mansoni, it was verified that the Egyptian strain was less pathogenic, despite the large number of worms produced in mice ${ }^{15}$. In our experiments, the total number of worms in infected mice was not related to the susceptibility of mollusks in which the cercariae developed, since mice infected by cercariae from mollusks treated with hydrocortisone (more susceptible) did notpresenta greater number of worms. However, cercariae from more susceptible mollusks ( mollusks treated with hydrocortisone) produced a greater number of female schistosomes and of coupled worms. The smaller number of male worms offset the increase in females to yield similar total numbers of worms in the two experimental groups. In S. mansoni infections, males frequently outnumber females.

Predominance of male worms may be related to some evolutionary singularity of the mollusk's larval stages, or to the greater vulnerability of female cercariae to destruction by the vertebrate host's defense mechanisms ${ }^{13}$. In the first of these hypotheses, the production of cercariae that result in female worms would be less intense than that of larvae that yield male worms. This difference could result from a slower release by the mollusks of cercariae for female worms such that over a given period a smaller number of females emerge compared to males. In this case, the infection of mollusks by larvae that will develop into females will last longer than infections by larvae that will give rise to males $^{13}$. Our results confirmed the first hypothesis. In previous experiments ${ }^{1718}$, we observed that mollusks treated with hydrocortisone were the first to eliminate cercariae. Since cercariae that gave rise to females emerged from mollusks treated with hydrocortisone more rapidly than non-treated mollusks, the percentage of female cercariae available to infect rodents would be greatest with the former group of mollusks.

Mating worms were observed mainly in the mesenteric vein, regarding the worms' displacement in preparation for mating and oviposition ${ }^{20}$. The greater number of coupled worms reflected the equal proportions between sexes and was not observed in mice infected with cercariae from mollusks untreated with hydrocortisone. This finding is important to the biology of schistosomes, since the somatic and germinative development of S. mansoni is dependent on the presence of both sexes and contact of the female with the male reproductive canal during mating is fundamental to development of the females. Hence, the females generally return to the male reproductive canal after oviposition ${ }^{20}$. The greater number of mating worms in the infections by cercariae from mollusks treated with hydrocortisone is an important factor in pathogenesis since the eggs produced by worms are responsible for unchaining the illness.
Treated mollusks showed a greater rate of infection and a greater release of cercariae. Since there was no difference in the number of penetrating cercariae, we concluded that the greater ease with which these larvae developed ${ }^{17} 18$ did not interfere with their ability to penetrate. Mice infected by cercariae from treated mollusks had a greater number of female worms and coupled worms and a smaller number of male worms, although the total number of worms was similar in both groups of mice. The mice infected by cercariae from treated mollusks released a greater number of eggs/gram of feces $(p<0.001)$, probably because of the larger number of mated worms $(p<0.0001)$, although the ratio of the number of eggs/gram of feces from coupled worms was not significantly different between the experimental groups $(p=0.1736)$. These findings corroborate those of other workers who have demonstrated that the conditions under which S. mansoni larvae develop within the mollusks affect the behavior of adult worms in the definitive host ${ }^{15} 21$.

\section{REFERENCES}

1. Bayne CJ, Buckley PM, Wan PC. Schistosoma mansoni: cytotoxicity of hemocytes from susceptible hosts for sporocysts in plasma from resistant Biomphalaria glabrata. Experimental Parasitology 50:409-416, 1980.

2. Coelho MV. Aspectos do desenvolvimento das formas larvais de Schistosoma mansoni em Australorbis nigricans. Revista Brasileira de Biologia 17:325-337, 1957.

3. Coelho MV. Susceptibilidade de Australorbis tenagophilus à infecção por Schistosoma mansoni. Revista do Instituto de Medicina Tropical de São Paulo 4:289-295, 1962.

4. Granath Jr WO, Yoshino TP. Schistosoma mansoni: passive transfer of resistance by serum in the vector snail Biomphalaria glabrata. Experimental parasitology 58:188-193, 1984.

5. Guaraldo AMA, Magalhães LA, Rangel HA, Pareja G. Evolução dos esporocistos de Schistosoma mansoni Sambon, 1907, em Biomphalaria glabrata ( Say, 1818) e Biomphalaria tenagophila (D'Orbigny, 1835). Revista de Saúde Pública 15:436-444, 1981.

6. Katz N, Chaves A, Pellegrino J. A simple device for quantitative stool thicksmear technique in Schistosomiasis. Revista do Instituto de Medicina Tropical de São Paulo 14:397-400, 1972.

7. Lemos Neto RC, Magalhães LA, Piedrabuena AE. Alguns aspectos referentes ao estudo de linhagem de Schistosoma mansoni Sambon, 1907 proveniente dos Estados de Minas Gerais e de São Paulo, Brasil. Revista de Saúde Pública 12:277-290, 1978.

8. Magalhães LA. Técnica para avaliação da viabilidade de penetração de cercárias de Schistosoma mansoni em Mus musculus. O Hospital 75:137-140, 1969.

9. Magalhães LA, Carvalho JF. Verificação do número de machos e de fêmeas de Schistosoma mansoni capturados em camundongos infectados com duas cepas do helminto. Revista da Sociedade Brasileira de Medicina Tropical 3:253-254, 1969 .

10. Magalhães LA, Carvalho JF. Desenvolvimento do Schistosoma mansoni das linhagens de Belo Horizonte ( MG) e de São José dos Campos ( SP) em Mus musculus. Revista de Saúde Pública 7:285-287, 1973.

11. Magalhães LA, Carvalho JF. Sobre o comportamento de duas linhagens de Schistosoma mansoni Sambon, 1907. Proposição para método de estudo quantitativo. Revista da Sociedade Brasileira de Medicina Tropical 10:169194, 1976.

12. Newton WL. The comparative tissue reaction of two strains of Australorbis glabratus to infection with Schistosoma mansoni. Journal of Parasitology 38:362-366, 1952

13. Paraense WL, Santos JM. 0 sexo do Schistosoma mansoni nas infestações produzidas por cercárias de um único molusco. Memórias do Instituto Oswaldo Cruz 47:35-49, 1949. 
14. Santana JV, Magalhães LA, Rangel HA. Seleção de linhagem de Biomphalaria glabrata e Biomphalaria tenagophila visando maior susceptibilidade ao Schistosoma mansoni. Revista de Saúde Pública 12:67-77, 1978.

15. Saoud, MFA. The infectivity and pathogenicity of geographical strains of Schistosoma mansoni. Transactions of the Royal Society of Tropical Medicine and Hygiene 60:585-600, 1966.

16. Schmid-Hempel P, Koella JC. Variability and its implications for host-parasite interactions. Parasitology Today 10:98-102, 1994.

17. Serrano DR, Zanotti-Magalhães EM, Magalhães LA, Carvalho JF. Influência da hidrocortisona no desenvolvimento de Schistosoma mansoni em Biomphalaria glabrata. Revista da Sociedade Brasileira de Medicina Tropical 35:149-153, 2002a.
18. Serrano DR, Zanotti-Magalhães EM, Magalhães LA, Carvalho JF. The influence of hydrocortisone on cellular defence mechanisms of Biomphalaria glabrata. Memórias do Instituto Oswaldo Cruz 97:881-885, 2002b.

19. Yolles TK, Moore PV, De Ginsti DL, Ripson CA, Meleney HE. A technique for the perfusion of laboratory animals for the recovery of Schistosoma mansoni. Journal of Parasitology 33:419-426, 1947.

20. Zanotti EM, Magalhães LA, Piedrabuena AE. Morfologia e desenvolvimento de Schistosoma mansoni Sambon, 1907, em infecções unissexuais experimentalmente produzidas no camundongo. Revista de Saúde Pública 16:114-119, 1982.

21. Zanotti-Magalhães EM, Magalhães LA, Carvalho JF. Relação entre a patogenicidade de Schistosoma mansoni em camundongos e a susceptibilidade do molusco vetor. I. Infecciosidade das cercárias e carga de vermes. Revista de Saúde Pública 25:359-366, 1991. 